\title{
Social Dimension of the Judicature of the Court of Justice. \\ Analysis on the Basis of Judgment in the Stehcempt Case (C-277/14)
}

\begin{abstract}
Socio-legal situation of Poland is now a lot different from the one before 2004. Membership of our country to an integrative organization with such an advanced character as the European Union causes that it is necessary to take a wider look at the issue of functioning of the political system patterns, as well as, as a consequence, at entities and methods which may be taken into account during public decision making. Here one of the most interesting issues, and as it seems - still least learned aspects of the EU governance is proceeding participation of the judicial sector of the EU within political life of the member states.

Aim of the author is to verify a research assumption that the CJ jurisdiction has a serious social dimension, noticeable also for Polish non-public actors. According to the principle of the CJ judicature, today named as quasi-precedent, each non-public body may point to previous judgements
\end{abstract}

1 Faculty of Political Science and International Studies, Nicolaus Copernicus University in Toruń, Poland. 
of the Court each time it assumes that it might have positive effects. But when we take into account how large that source is today possibility of such situation is high.

\section{Keywords:}

Court of Justice, European Union, multi-level governance, Polish citizens, non-state entities

\section{THE ESSENCE OF THE ACTIVITY OF THE COURT OF JUSTICE AND THE SOCIAL DIMENSION OF ITS JUDICATURE}

The European Union (EU) is the most structurally advanced international organization in the world. It is characterized by a unique structure and methods of functioning, which create a framework for legal mechanisms that do not have direct equivalents in the national systems (See Barcz, Wyrozumska \& Górka, 2010). Membership of our country in the EU makes it necessary to take a broader view on the problem of the native political system as a part of a multidimensional structure referred to as multi-level governance. It is a structure where decisions can be made cooperatively simultaneously on many levels (these levels include: local, regional, national, and supranational), sometimes omitting the government level, and, increasingly, in cooperation with public and non-public entities (See Ruszkowski 2013, pp. 19-60). In spite of more than 10 years of membership, the Polish authorities and the society are still "learning to participate" in the integration process. They are learning to fulfil the resultant duties and also to enjoy new rights and new instruments to protect them.

One of the most interesting and it seems still the least understood aspects of that relationship is the growing participation of the EU judicial bodies in the political life of the member states. Its most important task is exercising control over compliance with EU law by member states and EU institutions, as well as ensuring uniform application of EU law (See TEU, Article 19). The main role is played by the Court of Justice (CJ), the highest instance in the EU judicial system. In order to fulfil its tasks, the Court has very extensive judicial powers (See e.g. Mouton \& Soulard 2000, Koncewicz 2003, Stone Sweet 2004, Stone Sweet 2010, Brodecki 2007). It can for example rule on violation of treaties by member states (TFEU, Article 258, 259). It can also give the so-called preliminary rulings (TFEU, Article 267) on the questions raised by national courts on interpretation of EU law, which arose in connection with application of said law in a particular case. This 
competence allows the Court to determine the meaning of particular provisions of EU laws and, consequently, to de facto determine the scope of the legal norm, i.e. to reconstruct from the text of the legal provision an imperative specifying who and in what circumstances ought to behave in a specified way (Morawski 2002, pp. 55-57).

This is such a far-reaching competence that at the current stage of development of the EU some researchers (See Craig \& de Burca 1996, Shaw 1996, Piontek 2003) in order to describe the causative power of the CJ judgements use notions that are similar to legal precedents. Due to the different nature of EU law and common law, it is impossible, of course, to use the term "precedent" directly. This is why the effectiveness of the Court's judgements is often described by the term “quasi-precedent” (e.g. see Piontek 2003, p. 126). In essence, this means that each entity in the EU, including individual citizens, can refer to earlier judgements of the Court every time when they conclude these judgements provide them any advantage. And this is very likely, considering how complex this source is today. Until 2015, the Court alone issued 10,612 judgements and opinions (CURIA 2015, p. 96). It would therefore appear that this is a serious legal tool, which should strengthen the position of citizens or, in a wider perspective, non-state entities in achieving their goals and meeting their needs. This is especially important since often they encounter obstacles created for example by native authorities, which often have conflicting interests, such as increasing tax revenues or limiting social spending in order to maintain an adequate level of state finances. If this is done in accordance with the law, then it is a matter to settle at the level of a political dispute. However, if the authorities seek to pursue their goals in violation of the rights of non-state entities, it becomes apparent how the social dimension of the legal protection resulting from the CJ judicature may be useful.

This of course leads to the question whether the mechanism presented above is only a theoretical construct or whether there really is a possibility that it is useful for individual citizens. Is the CJ judicature applicable only to "distant matters of the distant Union” or can the Court's judgements actually have an impact on the lives of individual citizens? This question is especially topical given that recently more and more opinions are voiced that Polish citizens have decreasing possibilities of influencing their lives through membership in the EU and that our membership in this organization has more disadvantages than advantages.

The aim of this analysis is a kind of fragmentary survey concerning the entire presented legal and social mechanism. It is to confirm or disprove the thesis that the Court judicature in the chosen timeframe was an important element for the functioning of the Polish society. The demonstration of such a relationship in the 
chosen time range ought to make the possibility of its repetition in the future more probable and, considering the overall number of CJ judgements, make it almost certain that such a situation will occur in the future. Therefore, this analysis is also intended both as a voice in the discussion on the importance of the CJ judicature in the lives of Polish citizens and also as a opinion on the possibilities (instruments) that participation in the process of integration gives us access to in our daily lives.

The substantive scope of this analysis is of course narrowed down to the CJ judicature, but for the clarity of arguments, it should also have a clearly identifiable social result. Therefore the analysis will include such cases that fulfil both below conditions. Firstly, there is a possibility that the Court's ruling is used by a citizen not directly involved in the case in his daily life. Secondly, the potential number of such cases is so large that it is possible to classify such a ruling as having impact on the functioning of the entire Polish society. In turn, the temporal scope of the research was narrowed to the years 2015-16 as the latest period of Polish history in the EU. Referring to previous years is allowed when it is necessary to determine the facts of a case. In case of making a prediction as to the further development of the subject matter of the analysis, it will be possible also to refer to the future beyond this timeframe.

The method used to achieve this objective will be primarily a legal interpretation of the text, analysis of doctrine studies as well as overt participant observation². Also the initial study resulting from the research activities of the author will allow a pre-selection.

\section{SELECTED CASES OF THE COURT OF JUSTICE WITH A VISIBLE EFFECT ON THE GENERAL PUBLIC IN THE POLISH POLITICAL SYSTEM}

\subsection{ONLY TWO CASES? JUDGMENT ON EXCISE DUTY AND BENEFITS OF MS HALINA NERKOWSKA}

First, it must be noted that within the short history of our membership in the EU, although with difficulty, it is possible to identify at least two cases that meet the previously chosen criteria of a case with an identifiable effect on the general public. And so, perhaps the most famous CJ judgement that caused effects for Polish citizens is the case on excise duty of 2005. This matter was especially important

2 The author on multiple occasions prepared legal analyses on the basis of CJ judgements as well as letters subsequently used in disputes with the public administration. 
since importing vehicles from Western Europe (especially Germany) is common in our country. The introduced rates differentiated between cars purchased in the country and another EU country if they exceed the age of two years (See Law (2004/257), Article 76, 80, 81; Regulation of the Minister of Finance (2004/825), $\S 2, \S 7)$. These are the vehicles that are purchased by the majority of Polish citizens. Formally, the obligation to pay excise duty in the rate proportionate to the age of the car was applicable to all vehicles that were subject to registration in Poland. However, it is necessary to remember that a car bought in Polish dealerships and sold in the country was not subject to excise duty. It was already registered in our market and transfer of ownership did not introduce any change in this respect. Taking into account the scale of the phenomenon of importing used cars and the importance of a car for functioning of a person in the modern world, the decision of the Polish authorities was becoming a matter of almost existential character. In its decision, the Court ${ }^{3}$ held that a system of taxation may be considered compatible with Article 90 TEC (now TFEU, Article 110) only if it is proven that it is constructed in such a way that it prevents imported products being taxed more heavily than domestic products. And, therefore, that it does not have any discriminatory effect. Consequently, the Court, referring to the situation in question, concluded that the Polish provisions in the extent that they introduce distinction in taxation of goods (cars) acquired in Poland and other EU countries run counter to the Treaties (CJ Judgment 2007, Points 40-41). As a result, import of used cars to Poland could be continued without interruption and a significant number of affected citizens could recover overpaid tax. ${ }^{4}$

The second case, which was widely publicized and meets the accepted criteria, was the case of Ms Nerkowska, a Polish citizen living in Germany ${ }^{5}$. She decided to exercise her rights under the Polish law that guaranteed payment of certain benefits to its citizens on account of forced relocation to the USSR (See Law (1974/117), Article 12, Paragraph 2 and Law (1991/1975), Article 3). The condition, however, was that the person applying for such a benefit ought to continuously reside in the country (Law (1974/117), Article 5). Using this argument, the Social Insurance

3 It was an answer to the prejudicial question referred by the Wojewódzki Sąd Administracyjny w Warszawie in the case Brzeziński vs Dyrektor Izby Celnej w Warszawie on the calculated excise duty.

4 Under the condition that they applied for tax return prior to the end of the proceedings before the CJ.

5 Ms Halina Nerkowska who is a Polish citizen was born in 1946. In 1951 she was deported to the former USSR, where she lived under difficult conditions until 1957. Afterwards she returned to Poland. In 1985 she left Poland and settled permanently in Germany. 
Institution (Zakład Ubezpieczeń Społecznych, ZUS) refused her application for benefits she filed in $2006^{6}$. She referred the matter to court, which in turn directed the question to the CJ. It concerned the question whether the abovementioned Polish regulations do not hinder the exercise of freedom of movement guaranteed by the treaties (See TEC, Article 18, currently TFEU, Article 21). In its judgment, the Court accepted as true that the continuation of payment of a disability pension may be conditioned by such issues as the existence of a connection between a person entitled to benefits and the Polish society. It ruled, however, that the categorical requirement of residence as stipulated in the Polish law must be held to be disproportionate, since it goes beyond what is necessary to ensure that such a connection exists. The Court concluded that the Polish regulations that place certain citizens at a disadvantage simply because they have exercised their freedom to move and to reside in another member state are a restriction on the freedoms conferred on every citizen of the EU. It added that national regulations must not deter citizens from exercising their freedom of movement (CJ Judgement 2008, Points 22, 27-28, 31-34). Bearing in mind that in case of the CJ judgments, the general rules they include are the most important, we can say that this particular judgment may constitute a valuable argument for every citizen of our country, who considers that national legislation directly or indirectly hinders his freedom of movement in the EU common market.

\subsection{THE YEARS 2015-16 AND THE COURT'S RULINGS SIGNIFICANT FOR THE GENERAL PUBLIC IN THE POLISH POLITICAL SYSTEM}

Both of the cases presented above were widely publicized by the media. However, this may lead to doubt whether these really were the most important cases when the Court delivered judgments significant for the general public in Poland. Recently no cases that would meet the established criteria hit the headlines. In contrast, more and more frequent is information on the alleged weakening of the position of the Polish society in dealing with all kinds of public entities or representatives of the world of big business as a result of our membership in the EU. However, this assertion seems to be contradicted by even a brief overview of the cases that were examined by the Court in recent times.

6 Ms Nerkowska submitted an application for the first time in 2002. Then ZUS decided that she was entitled to a benefit, but it suspended payment of the disability pension on the ground that she did not reside in Polish territory Interestingly, ZUS adopted a similar decision when she submitted an application for the second time in 2006 (Opinion of Advocate General of 2008, Point 9). 
Here special attention shall be put especially to the judgement of 22nd October, 2015 in case Stehcemp (CJ judgemnet 2015a). In this particular case, in 2004, PPUH Stehcemp made a number of purchases of diesel fuel which it used in the course of its economic activity. The invoices relating to those fuel purchases were issued by Finnet sp. z o.o. ('Finnet'). PPUH Stehcemp deducted the value added tax (VAT) paid in respect of those fuel purchases. Following a tax inspection, the tax authorities, by decision of 5 April 2012, refused to allow PPUH Stehcemp to deduct that VAT on the ground that the invoices corresponding to those fuel purchases had been issued by a non-existent trader.. The Director of the Tax Chamber in Łódź upheld that decision, by decision of 29 May 2012, on the ground that Finnet was to be regarded, in the light of the criteria provided for by the Decree of 27 April 2004, as a non-existent trader incapable of supplying goods. The finding that Finnet was a non-existent trader was based on the overall evidence, including the fact that that company was not registered for VAT purposes, did not submit a tax return and did not pay any taxes. In addition, that company did not publish its annual accounts and did not have a concession for the sale of liquid fuels. The building designated in the commercial register as being its corporate seat was in a dilapidated state, making any economic activity impossible. Finally, all attempts to contact Finnet or the person registered as its director in the commercial register had proved to be unsuccessful (See CJ judgement 2015a, Points 17-19).

PPUH Stehcemp brought an action before the Wojewódzki Sąd Administracyjny w Łodzi (Regional Administrative Court, Łódź) against the decision of the Director of the Tax Chamber of Łódź of 29 May 2012. That action was dismissed on the ground that Finnet was a non-existent trader on the dates of the transactions at issue in the main proceedings and that, according to the Court, PPUH Stehcemp had not demonstrated due diligence by reason of its failure to ascertain whether those transactions were connected with fraud. PPUH Stehcemp brought an appeal on a point of law before the Naczelny Sąd Administracyjny (Supreme Administrative Court), invoking a breach of the VAT Law (Law (2004/535, Article 86(1), 86(2)(1)(a)) read in conjunction with Article 17(2) of the Sixth Directive (Council Directive 77/388/EEC). In support of its appeal on a point of law, PPUH Stehcemp submited that it is contrary to the principle of neutrality of VAT to deprive a taxable person, acting in good faith, of the right of deduction. It states that it received registration documents from Finnet indicating that that company was lawfully entitled to carry on trade, namely an extract from the commercial register, the allocation of a tax identification number and a certificate stating that it had been allocated a statistical identification number. (See CJ judgement 2015a, Points 20-22). In those circumstances, the Naczelny Sąd Administracyjny 
(Supreme Administrative Court) decided to stay the proceedings and to refer to the Court of Justice for a preliminary ruling (SAC decision 2014). By its questions, the referring court asked, in essence, "whether the provisions of the Sixth Directive are to be interpreted as precluding national legislation (...), by which a taxable person is not allowed to deduct the VAT due or paid in respect of goods that were delivered to him on the grounds that the invoice was issued by a trader which is to be regarded, in the light of the criteria provided by that legislation, as a non-existent trader and that it is impossible to establish the identity of the party which actually supplied the goods” (CJ judgement 2015a, Point 25).

The Court of Justice, after analysis of the case, recognized the invoices relating to the transactions at issue in the main proceedings mentioned, in accordance with that provision, inter alia, the nature of the goods supplied and the amount of VAT due, and also Finnet's name, tax identification number and the address of its corporate seat. The Court of Justice has then stated that according to the interpretation of the Sixth Directive formal conditions to deduct the VAT tax by the Polish company has been fulfilled. Furthermore, the CJ has acknowledged that the Polish company has also fulfilled material conditions to deduct the VAT tax. It actually received and paid for the goods concerned, namely fuel, indicated on the invoices issued by Finnet and that it used those goods subsequently for the purposes of its taxed transactions (see CJ judgement 2015a, Points 28-30, 42).

The Court of Justice has contested practice of Polish tax organs, pointing out that, according to the EU law interpretation (the Sixth Directive) it is the tax organs, that have detected crimes or abnormalities, which the invoice issuer has committed, are oblidged to evidence that the recipient of the invoice knew or shall know that the transaction, which is the legal basis for tax deduction has been a crime within VAT tax. A taxable person should be allowed to deduct the VAT due or paid in respect of goods that were delivered to him, even though that the invoice was issued by a trader which is to be regarded, in the light of the criteria provided by that legislation, as a non-existent trader, except where it is established, beyond any doubt, that that taxable person knew, or should have known, that that transaction was connected with VAT fraud. According to the CJ the tax authorities cannot, as a general rule, require that taxable person to ensure that the issuer of the invoice relating to the goods and services in respect of which the exercise of that right to deduct is sought was in possession of the goods at issue and was in a position to supply them and that he has complied with his obligations as regards the declaration and payment of VAT (see CJ judgement 2015a, Point 52-53). One may state then, that the decision of the Court of Justice definitely protects taxpayers, who act in good will, but who were mislead by their contractors. It could be also an 
important legal tool during potential quarrels with public (tax) institutions. Clear interpretation presented by the Court may stabilize the sphere of social need of legal certainty and protection of entities acting in good will within economic trade. It seems allowed then to take the above judgement as the confirming argument of the initial hypothesis.

Importantly, the validity of the research hypothesis adopted at the beginning seems to be confirmed by another essential aspect of the functioning of the CJ. It is necessary to remember that the principle of quasi-precedent character of judgments of the Court also means that significance for the national legislation, for example Polish, is held also by those cases that did not relate directly to the entities of our country. Each of the judgments is a potential source of interpretation of EU law. This is the basis on which legal relations can be (and are) created also in Poland. Here an example from the last year can be the CJ judgment of 6 October 2015 in the Schrems case. The Court expanded the range of actual powers granted to private entities in connection with protection of personal data published on Facebook accounts, which would be transferred to servers outside the EU (and more specifically to the USA). In this case an Austrian citizen, Mr Schrems, no longer wished the data from his Facebook account to be transferred to the United States, where he considered that the protection of personal data against surveillance by the intelligence services was insufficient. The supervisory authority in Ireland ${ }^{7}$ (where Mr Schrems lodged a complaint ${ }^{8}$ ) considered that it was prevented, by a European Commission decision (Commission decision 2000/520/EC), from carrying out the relevant check. This prompted Mr Schrems to bring proceedings before the High Court of Ireland, which, in turn, requested the Court of Justice to rule on the scope and the validity of the Commission decision. The Court of Justice ruled that the Commission decision of 2000, according to which the level of protection afforded by the United States was sufficient for personal data to be transferred from the European Union to that country, was invalid. The Court of Justice concluded that the United States 'Safe Harbour' rules, on which the

7 The European Data Protection Directive provides that each Member State is to designate one or more public authorities responsible for monitoring the application within its territory of the national provisions adopted on the basis of the directive ("national supervisory authorities") (Directive 95/46/EC: Article 28).

8 Any person residing in the European Union who wishes to use Facebook is required to conclude, at the time of his registration, a contract with Facebook Ireland, a subsidiary of Facebook Inc. which is itself established in the United States. Some or all of the personal data of Facebook Ireland's users who reside in the European Union is transferred to servers belonging to Facebook Inc. that are located in the United States, where it undergoes processing (CJ judgment 2015b, Point 28). 
Commission had relied, apply only to United States undertakings and therefore do not guarantee protection against access by the United States authorities to data transferred from the Member States of the European Union. It further stated that, irrespective of the existence of a Commission decision, the national supervisory authorities have the task, at the request of a citizen or an undertaking, of examining whether a non-member country offers an adequate level of protection. Accordingly, it is for the Irish supervisory authority to check whether the United States affords a level of protection substantially equivalent to that guaranteed in the European Union, so that the data provided to Facebook by Mr Schrems as a subscriber may be stored on servers in the United States. (CJ judgment 2015b, See Points 27-32, 91-99, 106). It is undoubtedly true that as a result of this judgement similar rights are held by each Polish entity that uses Facebook social networking site.

Another category of judgements that may be significant for the Polish society are for instance those dealing with consumer protection. Noteworthy judgements in this group include a judgment on the rights of passengers whose flight was cancelled and a judgement on how a producer can mislead the buyer through packaging design. In the first of these cases the Court of Justice confirmed that, under a European regulation, the air carrier must pay compensation (of between EUR 250 and 600) to passengers if their flight is cancelled. That obligation also applies in the event of unforeseen technical problems with the aircraft, since even in such a case air carriers are required to compensate the passengers. Only in very exceptional cases (hidden manufacturing defects affecting the safety of flights, acts of sabotage or terrorism) can air carriers be relieved of their obligation (See CJ judgment 2015c). And in the second one, the Court of Justice pointed out that EU law requires the consumer to have correct, neutral, and objective information. Where the labelling gives the impression that an ingredient is present when it is not in fact present, the purchaser may be misled, even though the list of ingredients is correct (See CJ judgment 2015d).

\section{CONCLUSIONS}

Membership of our country to an integrative organization with such an advanced character as the European Union causes that it is necessary to take a wider look at the issue of functioning of the political system patterns, as well as, as a consequence, at entities and methods which may be taken into account during public decision making. One of the elements of the EU structure, which activity shall be regarded in that context is the Court of Justice and its judgements. 
Judgements of the CJ are now becoming the integral part of the system, within which Polish legal norms are being reconstructed. Analyzed examples show how important, for each non-public entity, might be skills and habits of making use of rights granted to it by the EU law. That also includes legal steps in case of possible conflicts aimed at protection of that rights. Especially within conflicts with public bodies. It is being proved by judgments of the CJ in regard to excise tax, benefits of Mrs. Nerkowska, as well as the Stehcepm company. Above statements are important if take into account the number of the CJ judgments, meaning potential sources of the EU law interpretation, exceeds nowadays ten thousand.

A demand for broad information on the very process, as well as on consequences resulting from the fact that the Court of Justice has become an immanent part of Polish political system seems necessary. The issue is definitely an important start for further legal and political science research.

\section{References:}

Barcz, J., Wyrozumska, A., Górka, M. (2011). Instytucje i prawo Unii Europejskiej, Warszawa: LexisNexis.

Brodecki, Z. (2007). Europa sędziów. Warszawa: LexisNexis.

Commission decision 2000/520/EC of 26th July 2000 pursuant to Directive 95/46/EC of the European Parliament and of the Council on the adequacy of the protection provided by the safe harbour privacy principles and related frequently asked questions issued by the US Department of Commerce, OJ EC 2000 L 215.

Craig, C., de Burca, G. (1996). EC Law: Text, Cases \& Materials. Oxford: Oxford University Press.

CURIA (2015). Trybunał Sprawiedliwości Unii Europejskiej. Sprawozdanie roczne za 2015. Retrieved from http://curia.europa.eu/jcms/upload/docs/application/pdf/2016-04/ rapport_annuel_2015_activite_judiciaire_pl.pdf.

Decision of the Supreme Administrative Court (2014) of 6th March 2014 in the case I FSK 516/13, PPUH Stehcemp sp. J. Florian Stefanek, Janina Stefanek, Jarosław Stefanek vs Dyrektor Izby Skarbowej w Łodzi, http://orzeczenia.nsa.gov.pl/doc/DE09E621B9. Directive 95/46/EC of the European Parliament and of the Council of 24th October 1995 on the protection of individuals with regard to the processing of personal data and on the free movement of such data OJ EC 1995 L 281.

Judgement of the Court of Justice (2007) of 18th January 2007 in the case C-313/05, Maciej Brzeziński vs Dyrektor Izby Celnej w Warszawie, ECLI:EU:C:2007:33.

Judgement of the Court of Justice (2008) of 22nd May 2008 in the case C-499/06, Halina Nerkowska vs Zakład Ubezpieczeń Społecznych, Oddział w Koszalinie, ECLI:EU:C:2008:300.

Judgement of the Court of Justice (2015a) of 22nd October 2015 in the case C-277/14, 
PPUH Stehcemp sp. J. Florian Stefanek, Janina Stefanek, Jarosław Stefanek vs Dyrektor Izby Skarbowej w Łodzi, ECLI:EU:C:2015:719.

Judgement of the Court of Justice (2015b) of 6th October 2015 in the case C-362/14, Maximillian Schrems vs Data Protection Commissioner, joined party: Digital Rights Ireland Ltd, ECLI:EU:C:2015:650.

Judgement of the Court of Justice (2015c) of 17th September 2015 in the case C-257/14, van der Lans, Corina van der Lans vs Koninklijke Luchtvaart Maatschappij NV, ECLI:EU:C:2015:618.

Judgement of the Court of Justice (2015d) of 4th June 2015 in the case C-195/14, Bundesverband der Verbraucherzentralen und Verbraucherverbände - Verbraucherzentrale - Bundesverband e.V. vs Teekanne GmbH \& Co. KG, ECLI:EU:C:2015:361.

Koncewicz, T. (2003). Trybunał Sprawiedliwości i Sq̨d Pierwszej Instancji Wspólnot Europejskich. Warszawa: Wydawnictwo Sejmowe.

Law (1974/117) of 29th May 1974 on provision for war and military invalids and their families (ustawa o zaopatrzeniu inwalidów wojennych i wojskowych oraz ich rodzin), Dz. U. RP 1974 No 21 heading 117, as amended Dz. U. RP 2002 No 9 heading 87.

Law (1991/75) of 24th January 1991 on combatants and certain persons who are the victims of wartime and post-war repression (ustawa o kombatantach oraz niektórych osobach będących ofiarami represji wojennych i okresu powojennego), Dz. U. RP 1991 No 17 heading 75, as amended Dz. U. RP 2002 No 42 heading 371.

Law (2004/257) of 23rd January 2004 on Excise Duty (ustawa o podatku akcyzowym), Dz. U. RP 2004 No 29 heading 257 with further amendments.

Morawski, L. (2002). Wstęp do prawoznawstwa. Toruń: TNOiK.

Mouton, J.D., Soulard, Ch. (2000). Trybunał Sprawiedliwości Wspólnot Europejskich. Lublin: Wydawnictwo Uniwersytetu Marii Curii-Skłodowskiej.

Opinion of Advocate General Poiares Maduro of 28th February 2008 in the case C-499/06, Halina Nerkowska vs Zakład Ubezpieczeń Społecznych, ECLI:EU:C:2008:132.

Order of the Minister for Finance of 22nd April 2004 on the lowering of the rates of excise duty (rozporządzenie ministra finansów w sprawie obniżenia stawek podatku akcyzowego), Dz. U. RP 2004 No 87 heading 825.

Piontek, E. (2003). Doktryna i praktyka acte cłair a wspólnotowy porzqdek prawny w kontekście funkcji artykułu 234 TWE. In: E. Piontek (ed.). Prawo polskie a prawo Unii Europejskiej, Konferencja Wydziałowa Wydziału Prawa i Administracji UW. Warszawa: Liber sp. z o. o.

Ruszkowski, J. (2013). Struktura wielopoziomowego zarzqdzania w Unii Europejskiej. In: J. Ruszkowski, L. Wojnicz (eds.) (2013). Multi-level governance w Unii Europejskiej. Szczecin-Warszawa: Wyd. Instytut Politologii i Europeistyki USz oraz Instytut Europeistyki UW.

Shaw, J. (1996). Law of the European Union. London: Palgrave.

Stone Sweet, A. (2004). The judicial construction of Europe. New York: Oxford University Press.

Stone Sweet, A. (2010). The European Court of Justice and the judicialization of EU governance. Living Reviews in European Governance, 2(5). 
TEC (2002): Treaty establishing the European Community, consolidated version of the 2002, OJ EC 2002 C 325/33.

TEU (2002): Treaty on European Union, consolidated version of the 2002, OJ EC 2002 C 325.

TFEU (2012): Treaty on the Functioning European Union, consolidated version of the 2012, OJ EU 2012 C 326/47.

The Sixth Directive: Directive 77/388/EEC of 17th May 1977 on the harmonisation of the laws of the Member States relating to turnover taxes - Common system of value added tax: uniform basis of assessment, OJ EEC 1977 L 145, as amended by Council Directive 2002/38/EC of 7th May 2002, OJ EC 2002 L 128.

The VAT Law: Law (2004/535) of 11th March 2004 on the tax on goods and services (ustawa o podatku od towarów i usług) of 11 March 2004, Dz. U. RP 2004 No 54 heading 535. 